UDC 349:61

DOI https://doi.org/10.32849/2663-5313/2021.7.03

Olha Rossylna,

PhD in Law, Managing Partner, Clinic for Personalized Diagnostics and Therapy Design "ONCOTHERANOSTICS", 45, Vasylkivska street, Kyiv, Ukraine, postal code 03022, rossylna@gmail.com

ORCID: orcid.org/0000-0002-1648-6063

Rossylna, Olha (2021). Biobanking in oncology as an element of personalized medicine: legal interaction aspects. Entrepreneurship, Economy and Law, 7, 18-21.

\title{
BIOBANKING IN ONCOLOGY AS AN ELEMENT OF PERSONALIZED MEDICINE: LEGAL INTERACTION ASPECTS
}

Abstract. Purpose. The modern scientific and medical community has made significant progress in its development over the last century. Unfortunately, domestic healthcare legislation is not developing so fast. Therefore, the purpose of the article is to highlight the main areas of reforms of the national biobanking laws, conduct research and analyze the relevant relations, impact and legal mechanisms of interaction between personalized medicine and biobanking. Research methods. The paper relies on general research and special methods of scientific cognition. Results. The basic issues of interaction between biobanking and personalized medicine have been analyzed. The concept of biobanking as an economic activity has been defined. The article pays special attention to the justification of the urgent public need to improve health legislation, in particular, to regulate activities related to human biological material. The author has determined the significance, value and necessity of legalizing biobanking in clear, unified and transparent legal field. It has been proved that one should highlight key legal points taking into account the protection of intellectual property rights to medical data. This is associated with the shift of a focus from the strategy centered on samples to the strategy that is primarily oriented to relevant data. The article has studied different models of biobanking funding and substantiated the feasibility of implementing an entrepreneurial model in Ukraine within the conditions provided by the laws on public-private partnership. Conclusions. In the context of rapid scientific development, large-scale research projects should pay due attention to the legal regulation of biobanking as an activity that leads to the integrated studies of personalized medicine. At this time, the legislator faces some challenges, the settlement of which will result in unshadowing and standardization of activities that are directly related to human biological material. Therefore, it has a range of risks and involves many stakeholders who have public and private interests in the mentioned activity.

Key words: biobanking, personalized medicine, biological material, medical law, international medical law, intellectual property right to medical data, public-private partnership in healthcare.

\section{Introduction}

It is evident that biobanking is an underestimated research topic. This is a tool that can contribute to implementing various projects: from the creation of more finegrained genetic tests to the discovery of drugs and new viruses. The science of biobanking is very comprehensive and diversified as it covers the collections of plant, animal, and human samples. To achieve the purposes set in this research, the author has focused on the very human biobanking. Any biomedical issues should be considered holistically given not only legal but also socio-economic and moral-ethical elements of the regulation of relevant social relations.

The concept "biobank" generally means large, organized collections of well- characterized tissue samples, such as surgical biopsy (fresh frozen or in paraffin blocks), blood, serum samples, diverse cell lines and DNA everything is thoroughly collected for research purposes (Parodi, 2015). Biobanking, in its turn, is an activity on sampling, technical processing and proper storage of biomaterial samples according to international standards for their further use for large-scale research purposes, in particular, in personalized medicine.

Personalized medicine is an efficient scientific and hi-tech approach to the healthcare system. Personalized medicine is a field of modern medicine that uses targeted diagnostic and therapeutic approaches. For common understanding, the essence of personalized medicine is somewhat simplified to the fact 
that a human being, not a disease, is central to treatment and medical mastery. Nowadays, there are about 75 thousand genetic testing products on the market compared to less than 66 thousand in 2016 (Waltz, Konski, 2020). Such availability of different genetic tests intensifies the need for additional requirements for patients' data protection.

\section{Statutory regulation of biobanking in} the context of personalized medicine

High-quality progress in the health system can take place only as a result of largescale research projects. Clinical research in personalized medicine is based on the analysis of biomaterial samples along with clinical data. Thus, as associative links between these two elements are often weak, qualitative research requires plenty of samples and accurate clinical data. Moreover, biobanks are one of the core platforms for international and interdisciplinary cooperation acting as a "key driver" for biomarkers (diagnostics) of the next generation and drug discovery (Hasan, 2012).

Personalized medicine and biobanking as two legal categories have something in common, as follows:

1) both are regarded in terms of one of the backbone branches of public administration - health care;

2 ) in the practical aspects of implementation, they deal with biological material (biological samples);

3) they are widely used in Ukraine and have considerable international experience of realization of social relations regulated by statutory acts on personalized medicine and biobanking;

4) none of them has well-defined legal regulation under the current legislation of Ukraine.

As early as 2009, Time Magazine added biobanking to the list of top 10 ideas changing the world right now. However, it is essential to note that back then, some European countries already had laws governing social relations on the creation and use of biobanks. For instance, the Act on Biobanks went into effect in Iceland in 2001; since then, the Human Genes Research Act has been in force in Estonia, as well as the Act on the Medical Use of Human Organs and Tissues in Finland; the Human Genome Research Law - in Latvia since 2002; the Biobanks Law and Biobanks in Medical Care Act - in Norway and Sweden, respectively, since 2003; the Act of the Hungarian Parliament on the protection of human genetic data and the regulation of human genetic studies, research and biobanks - since 2008. In 2011, Switzerland adopted the Human Research Act, and Finland approved the Biobank Law in 2012 (Morr, 2005).
It is worth mentioning that a logical process primarily involves shaping a particular circle of social relations, which is subsequently edged with statutory regulation. The process of the system and unified statutory regulation in personalized medicine (including biobanking) is somewhat delaying in Ukraine. The Resolution of the Cabinet of Ministers of Ukraine, which approved Licensing conditions for economic activities of banks of umbilical cord blood and other tissues and human cells, is one of the key normative-legal acts in this field (On approval of Licensing conditions for economic activities of banks of umbilical cord blood and other tissues and human cells according to the list approved by the Ministry of Health, 2016). This document doesn't have the definition of "biobanking", but it contains a similar one that can be used to trace some elements and logical focus of legislator's ideas, as follows: the activity of the umbilical cord blood bank is the economic activity on processing, labeling (coding), preservation, testing (examination), storage, provision (sale) and/or clinical use of products and/or drugs based on cord blood, other human tissues and cells.

In view of the aforesaid, the statutory regulation of biobanking, as one of the highpriority elements of personalized medicine, should be precise and transparent at all its stages:

- collection of biomaterial samples;

- processing - manufacturing of products and/or drugs based on human tissues and cells;

- proper storage of samples;

- provision with necessary clinical data.

Thus, the author states that biobanking in the context of current legislation is an economic activity in the health system that is exercised by licensed economic entities for processing, labeling (coding), preservation, testing (examination), storage, provision (sale) and/ or clinical use of products and/or drugs based on human biomaterials and related clinical data.

One of the most critical elements of biobanking is information - biological and medical (clinical) data on a biological sample. Such data are a basic driving precondition that is associated with the promotion by personalized medicine specialists of the development of modern biobanks. It is personalized medicine that guides modern biobanking and changes its focus from the strategy which is centered on samples to the strategy which is primarily oriented to relevant data.

The latest generation of biobanking is often linked with biological data kept in the electronic medical systems. In addition to the access to biological samples, the owners of such databases can also propose access to validated medical 
records, genetic data and extremely specific demographic information of a patient (Hasan, 2012). Biobanks will play a key role in switching to personalized medicine as they have the potential that geneticists search, record and analyze phenotypic information concerning a large number of patients as part of "the real world" (Roden, 2008; Hinrichsen, 2007; Lieu, 2007).

Specialists also warn of the danger of that sort of access to data because it can complicate carrying out duties and expectations of all users and owners, including scientists, research sponsors, companies and organizations maintaining coordination and development of science (Scott, 2012). The situation requires great joint efforts of regulatory bodies, scientific community, patient's groups and organizations, IPR specialists, lawyers, experts in the relevant field, and other stakeholders.

\section{Funding models of biobanking}

Keeping in mind the lack of a system statutory mechanism of biobanking realization, in particular, for clinical oncological research, and a dire need for developing a legal environment, it is incumbent to analyze another backbone element, i. e., a financing model of biobanking, in the absence of which the implementation of activities is impossible. For instance, Herbert Gottweis \& George Lauss distinguish three different types:

- an entrepreneurial model of biobanking, which is often reflected in a public-private partnership between commercial organizations and government institutions;

- a bio-social model in which active groups of patients promote, finance and assist in biobank's creating and functioning;

- a model of public biobank according to which a biobank is mainly maintained and supported at the expense of taxpayers and non-profit research organizations (Gottweis, 2012)
Ukrainehasallthereasonstoruntheso-called entrepreneurial model of biobanking financing. Regardless of the name, it is evident that the model grants public institutions a strong role: it refers to the situations when highstatus healthcare research institutions are the managers of biobanks. Pursuant to Art. 4 of the Law of Ukraine "On State-Private Partnership" (On State-Private Partnership, 2010), healthcare is one of the spheres of application of such a partnership mechanism between the state and private partners. Despite the intense discussion of the forms of partnership implementation, the relevant agreements are concluded once in a while and implemented even less. As reported by the Investment Department of the Ministry of Economy of Ukraine, 192 PPP contracts have been concluded dated January 1 2021, among which 39 are being executed (only 2 contracts in health care: in Kyiv and Lviv regions) (Status of PPP implementation in Ukraine, 2021). Thus, lagging progress in concluding and implementing PPP projects is associated with a high level of corruption risks for investors and imperfect legislation.

\section{Conclusions}

Given the above, the author has specified key challenges which should be kept in mind when developing a legal framework regulating social relations in biobanking, as follows:

1) standardization of activities in the biobanking realm to take part in the international large-scale research projects;

2) harmonizing all processes (from the collection of biomaterial samples to their adequate storage);

3) consideration of ethical aspects when collecting samples and respective clinical data (GDRP), as well as during their transfer to other subjects;

4) protection of intellectual property rights to medical data.

\section{References:}

Cabinet of Ministers of Ukraine (2016). Pro zatverdzhennia Litsenziinykh umov provadzhennia hospodarskoi diialnosti bankiv pupovynnoi krovi, inshykh tkanyn i klityn liudyny zgidno z perelikom, zatverdzhenym Ministerstvom okhorony zdorovia: Postanova Kabinetu Ministriv Ukraiiny vid 2 bereznia 2016 № 286 [On approval of Licensing conditions for economic activities of banks of umbilical cord blood and other tissues and human cells according to the list approved by the Ministry of Health: Resolution of Cabinet of Ministers of Ukraine March 2, 2016, no. 286]. Retrieved from: https://zakon.rada.gov.ua/laws/show/286-2016$\% \mathrm{D} 0 \% \mathrm{BF}$ (in Ukrainian).

Gottweis, H., Lauss G. (2012). Biobank governance: heterogenous modes of ordering and democratization. J. Community Genet., vol. 3(2), pp. 61-71 (in English).

Hasan, S. (2012). The increasing role of biobanks in personalized medicine. Sanguine Blog. Retrieved from: https://blog.sanguinebio.com/the-increasing-role-of-biobanks-in-personalized-medicine (in English).

Hinrichsen, V. L., Kruskal, B., O'Brien, M. A., Lieu, T. A., Platt, R. (2007). Using electronic medical records to enhance detection and reporting of vaccine adverse events. J. Am. Med. Inform. Assoc., no. 14(6), pp. 731-735 (in English)

Lieu, T. A., Kulldorff, M., Davis, R. L. et al. (2007). Real-time vaccine safety surveillance for the early detection of adverse events. Med. Care, 45(10 Suppl. 2), pp. 89-95 (in English). 
Morr, U. (2005). Zul ssigkeit von Biobanken aus verfassungsrechtlicher Sicht (Recht und Medizin, Band 77). Peter Lang GmbH, InternationalerVerlag der Wissenschaften, p. 187 (in German).

Parks, A. (2009). Biobanks - 10 ideas changing the world right now. Time Magazine, 12 March, no. 173(11). Retrieved from: http://content.time.com/time/specials/packages/arti cle/0,28804,1884779_1884782_1884766,00.html (in English).

Parodi, B. (2015). Biobanks: A definition. Ethics, Law and Governance of Biobanking / D. Mascalzoni (ed.). Dordrecht: The International Library of Ethics, Law and Technology 14, Springer Science and Business Media. DOI: 10.1007/978-94-017-9573-9 (in English).

Roden, D. M., Pulley, J. M., Basford, M. A. et al. (2008). Development of a large-scale de-identified DNA biobank to enable personalized medicine. Clin. Pharmacol. Ther., no. 84(3), pp. 362-369 (in English).

Scott, C. T., Caulfield, T., Borgelt, E., Illes, J. (2012). Personal medicine - the new banking crisis. Nat. Biotechnol., no. 30(2), pp.141-142 (in English).

Stan zdiisnennia DPP v Ukraini [Status of PPP implementation in Ukraine] (2021). Retrieved from: https://www.me.gov.ua/Documents/Detail?lang=uk-UA\&id=9fc90c5e-2f7b-44b2-8bf1-1ffb7ee1be26\&title= StanZdiisnenniaDppVUkraini\&isSpecial=true (in Ukrainian).

Verkhovna Rada Ukrainy (2010). Pro derzhavno-pryvatne partnerstvo: Zakon Ukrainy vid 1 lypnia 2010 № 2404-VI [On State-Private Partnership: Law of Ukraine, July 1, 2010]. Retrieved from: https://zakon.rada. gov.ua/laws/show/2404-17\#Text (in Ukrainian).

Waltz, J. A., Konski, A. F. (2020). Episode 12: Personalized Medicine, the Health Care of the Future. Health Care Law Today, Personalized Medicine Bulletin. Retrieved from: https:/www.foley.com/en/insights/ publications/2020/08/personalized-medicine-health-care-of-the-future (in English).

Ольга Россильна,

кандидат юридичних наук, керуючий партнер, Клініка персоналізованого дизайну діагностики $і$ терапї «ОНКОТЕРАНОСТИКА», вул. Васильківська, 45, Київ, Україна, індекс 03022, rossylna@gmail.com

ORCID: orcid.org/0000-0002-1648-6063

\section{БІОБАНКІНГ В ОНКОЛОГІї ЯК ЕЛЕМЕНТ ПЕРСОНАЛІЗОВАНОЇ МЕДИЦИНИ: ПРАВОВІ АСПЕКТИ ВЗАЕМОДІї}

Анотація. Мета. Сучасна наукова й медична спільнота зробила значний ривок у своєму розвитку впродовж останнього століття. На жаль, не такими швидкими темпами розвивається вітчизняне законодавство в галузі охорони здоров'я. Тому метою статті є виокремлення основних напрямів реформування національного законодавства у сфері біобанкінгу, проведення дослідження та аналіз зв’язку, впливу і правових механізмів взаємодії персоналізованої медицини та біобанкінгу. Методи дослідження. Робота виконана на підставі загальнонаукових і спеціальних методів наукового пізнання. Результати. Проаналізовано базові питання взаємодії біобанкінгу та персоналізованої медицини. Визначено поняття біобанкінгу як господарської діяльності. Особлива увага у статті приділяється обгрунтуванню гострої суспільної необхідності у вдосконаленні законодавства у сфері охорони здоров'я, зокрема, з метою врегулювання діяльності, пов'язаної з біологічним матеріалом людини. З'ясовано значення, цінність і необхідність легалізації біобанкінгу в чіткому, уніфікованому й прозорому правовому полі. Доведено, що юридичні акценти мають бути розставлені з урахуванням захисту прав інтелектуальної власності на медичні дані. Це пов'язано зі зміщенням фокусу зі стратегії, у центрі якої перебувають зразки, на стратегію, яка першочергово спрямовується на відповідні дані. Досліджено різні моделі фінансування біобанкінгу та доведено можливість реалізації в Україні підприємницької моделі в межах умов, передбачених законодавством про державно-приватне партнерство. Висновки. В умовах стрімкого наукового розвитку й у межах масштабних дослідницьких проєктів належне місце має бути відведене правовому регулюванню біобанкінгу як діяльності, яка зумовлює комплексні дослідження у сфері персоналізованої медицини. Наразі перед законодавцем постає низка викликів, урегулювання яких приведе, зокрема, до детінізації та стандартизації діяльності, що безпосередньо пов'язана з біологічним матеріалом людини. А тому зазначена сфера має низку ризиків та охоплює багато стейкхолдерів, які мають як публічні, так і приватні інтереси в такій діяльності.

Ключові слова: біобанкінг, персоналізована медицина, біологічний матеріал, медичне право, міжнародне медичне право, право інтелектуальної власності на медичні дані, державно-приватне партнерство у сфері охорони здоров’я. 